\title{
Combustion behavior of rotary solid porous burners (RSPB)
}

\author{
Niwat Ketchat $^{1}$, and Bundit Krittacom ${ }^{1 *}$ \\ ${ }^{1}$ Rajamangala University of Technology Isan, Faculty of Engineering and Architecture, Department of \\ Mechanical Engineering, Development in Technology of Porous Materials Research Laboratory \\ (DiTo-Lab), Nakhonratchasima, Thailand
}

\begin{abstract}
The combustion behavior of rotary solid porous burners (RSPB), i.e., temperature (T), exhaust gas (CO and $\mathrm{NOx})$ and combustion efficiency $\left.\eta_{\mathrm{C}}\right)$ were investigated. The stainless wire-mesh type of porous media was selected as porous absorber with porosity of 0.82 , thickness of $4.2 \mathrm{~mm}$. The rice husk was used as the fuel with the humidity around $12-14 \%$. The experiment showed that the $\mathrm{T}$ tends to increase following the rotating velocity $(\omega)$ rising around $0.5-1 \mathrm{rpm}$. When a $\omega$ increased to $1.5 \mathrm{rpm}$, a $\mathrm{T}$ had tendency decreasingly. Because, a $\omega$ was too high resulting in the fuel in combustion chamber were ejected quickly then the reaction time reduced not enough to burn fuel, leading to incomplete combustion. The air flow rate $\left(\mathrm{Q}_{\mathrm{A}}\right)$ of $40 \mathrm{~m}^{3} / \mathrm{h}$ and the fuel load input rate $\left(\mathrm{Q}_{\mathrm{F}}\right)$ of $2.3 \mathrm{~kg} / \mathrm{h}$, gave the highest of $\mathrm{T}$ due to the system become complete combustion. Corresponding to the level of CO, the least level was obtained at $\omega=1 \mathrm{rpm}, \mathrm{QF}_{\mathrm{F}}=2.3 \mathrm{~kg} / \mathrm{h}$ and $\mathrm{Q}_{\mathrm{A}}=40 \mathrm{~m}^{3} / \mathrm{h}$. The $\eta \mathrm{c}$ yielded highest with $93.7 \%$ at the same condition. The $\mathrm{NO}_{\mathrm{x}}$ in this research was considered as low, not more than $40 \mathrm{ppm}$ in all experimental conditions.
\end{abstract}

\section{Introduction}

In the past several decades, many researchers have been tried to find ways to create combustion technologies for effective and environmental friendly [1-4]. In order to use energy based on high valuable and low emission, porous burners was combustion technology that can solve these problems. Because porous materials had the ability to transform heat energy between convection and radiation. Therefore, if the combustion occurs in the porous media, the intake will be heated by exhaust gas using the heat transfer mechanism of the porous media itself, without addition heat exchangers in the process burn in any way. S. Jugjai et al. [5] studied the combustion characteristic of the liquid porous burner with many parameters such as equivalence ratios, thermal input installed the porous emitter. S. Jugjai and C. Pongsai [6] installed porous emitter in the porous burner so that radiating heat emitted to porous burner for evaporation and acting as a combustion burner in which the combustion occurs (Some or all) within it. T. Lakpradit and B. Krittacom [7] installed the porous emitter to the enhancement of the combustion of the liquid porous burner. B. Krittacom and

\footnotetext{
* Corresponding author: bundit.kr@,rmuti.ac.th
} 
P. Amatachaya [8] reported the combustion behavior of the porous burner with the porous emitter using the diesel oil as fuel. K. Keawchart and B. Krittacom [9] examined the influence of the stainless wire-mesh type of porous media on the combustion behavior solid porous burner. As mentioned above, most of the research was focused on porous emitter to increase the combustion efficiency, which was mainly based on heat radiation. Moreover, all were non-rotating. Therefore, the present work investigated the combustion behavior of rotary solid porous burner (RSPB). The temperature (T), the content of exhaust gas (CO and NOx) and the combustion efficiency $\left(\eta_{C}\right)$ were discussed in this work. In experiment, the solid fuel was rice husk with humidity in the range of $12-14 \%$ similar with previous works [9].

\section{Experimental}

Figure 1 showed the schematic diagram of a rotary solid porous burner (RSPB) with rotating combustion chamber. The major components of the experimental equipment consisted of 3 parts. The first part was the injection zone, respectively. The second and third part were solid fuel feeder zone and combustion chamber zone. In experiment, the rice husk with humidity in the range of $12-14 \%$ was used as solid fuel. A rice husk was supplied from the solid fuel port and, then, was flowed along a screw conveyer into combustion chamber as shown in Figure 2. The fuel was ignited by pilot flame resulting to combustion was occurred. The stainless wire-mesh having porosity $(\phi)$ of 0.82 and thickness $(\mathrm{H})$ of $4.2 \mathrm{~mm}$ was installed inside the chamber. The preheating process can be achieved by the cool air that was flowed passing this porous. The combustion zone was the rotary combustion chamber as propulsion unit for push the ash leave more conveniently from a combustion chamber. Meanwhile, the stainless wire-mesh type porous media had been used as porous absorber for preheating the supplying air. The combustion chamber was driven by motor. The rotating velocities of combustion chamber $(\omega)$ studied in the experiment were $0.5,1.0$ and $1.5 \mathrm{rpm}$. There were three fuel load input rate $\left(\mathrm{Q}_{\mathrm{F}}\right)$ as investigated: $1.7,2.3$ and $2.9 \mathrm{~kg} / \mathrm{h}$, and air flow rate $\left(Q_{A}\right)$ were 20,30 and $40 \mathrm{~m}^{3} / \mathrm{h}$. The combustion behavior of this work were the temperature $(\mathrm{T})$, the content of exhaust gas $(\mathrm{CO}$ and $\mathrm{NO})$ and the combustion efficiency $\left(\eta_{c}\right)$. The temperature $(T)$ was monitored using a data logger with a type-N thermocouple at the inlet $(\mathrm{x}=0 \mathrm{~cm})$ and exit $(\mathrm{x}=40 \mathrm{~cm})$ of the combustion chamber. The content of exhaust gas (CO and NOx) have been verified by Testo M350-Model and have been reported on by excess oxygen $0 \%$ on a dry basis. The combustion efficiency $\left(\eta_{c}\right)$ was defined by

$$
\eta c=\frac{E_{f}-E_{u}-E_{c o}}{E_{f}}
$$

where $E_{f}, E_{u}$ and $E_{c o}$ were energy of fuel $(k J)$, energy of unburned fuel $(k J)$ and energy loss as $\mathrm{CO}$ in the exhaust gas $(\mathrm{kJ})$, respectively. 


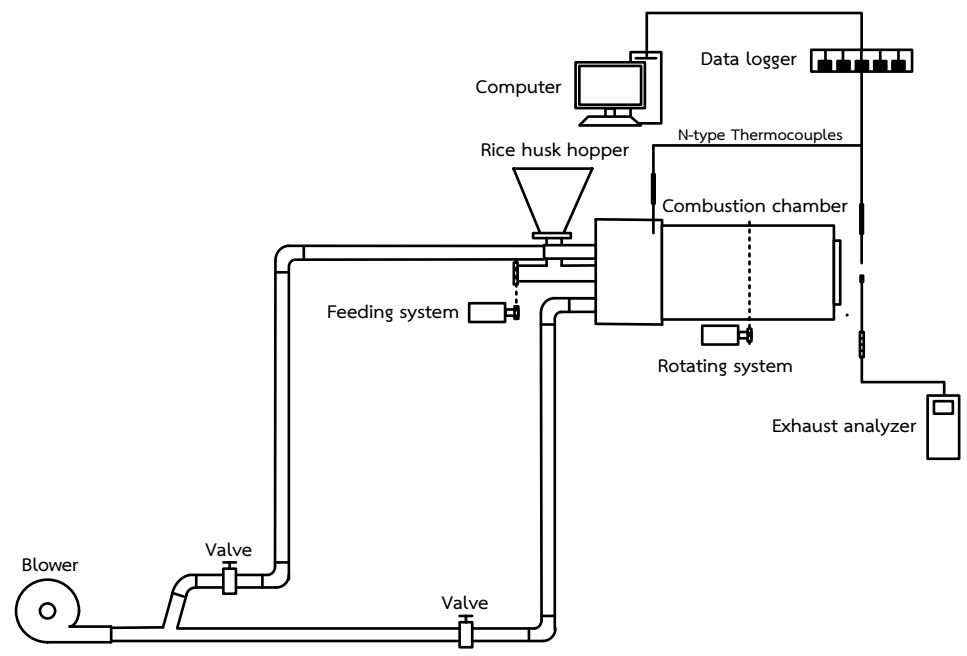

Fig. 1. Schematic diagram of a rotary solid porous burner (RSPB).
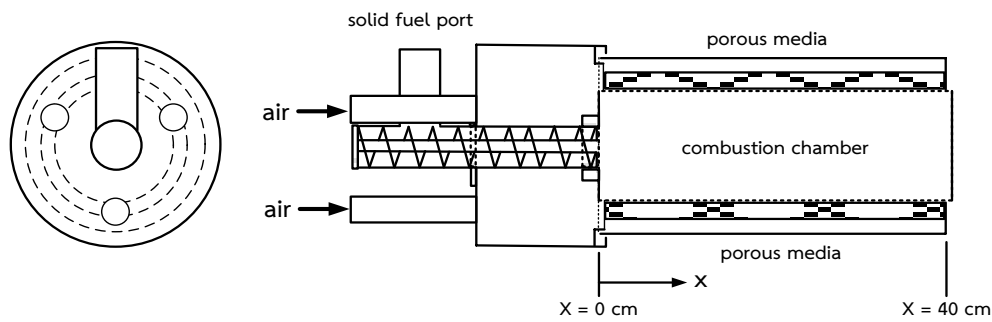

Fig. 2. Axial cross-section of a rotary solid porous burner (RSPB).

\section{Results and discussion}

\subsection{Effect of the rotating velocity of combustion chamber $(\omega)$}

Figure 3 showed the effect of the rotating velocity of combustion chamber $(\omega)$ on the inlet temperature $\left(\mathrm{T}_{\text {in }}\right)$ and the exit temperature $\left(\mathrm{T}_{\text {exit }}\right)$ of the combustion chamber. The condition studied in the experiment were the fuel load input rate $\left(\mathrm{Q}_{\mathrm{F}}\right)$ of $2.3 \mathrm{~kg} / \mathrm{h}$, the air flow rates $\left(\mathrm{Q}_{\mathrm{A}}\right)$ of $40 \mathrm{~m}^{3} / \mathrm{h}$, the porous absorber thickness $(\mathrm{H})$ of $4.2 \mathrm{~mm}$ and the porosity $(\phi)$ of 0.82 . It was found that the trend of $T_{\text {in }}(x=0 \mathrm{~cm})$ was average of $40-45^{\circ} \mathrm{C}$. As for the $T_{\text {exit }}(x=40$ $\mathrm{cm})$, it was increased with $\omega$ increasing from 0.5 to $1 \mathrm{rpm}$, but when the $\omega$ become increased to $1.5 \mathrm{rpm}$, it was found that a $\mathrm{T}$ had a downward trend. This phenomenon can be explained that when $\omega$ was too high, solid fuel (rice husk) was expelled from the combustion chamber, enabling rapid time to react less insufficient fuel combustion. Which was consistent to $\omega$ increasing of carbon monoxide (CO) in Figure 4. As increasing, the level of $\mathrm{NO}_{\mathrm{X}}$ was quite low as increasing $\omega$ and was in the range not over $40 \mathrm{ppm}$. Similar phenomena of thermal $\mathrm{NO}_{\mathrm{X}}$ process had also been found in the literature [9]. Figure 5 shows the effect of the $\omega$ on the combustion efficiency $\left(\eta_{C}\right)$. The highest $\eta_{C}$ of an average of $93.7 \%$ was achieved at $\omega=$ $1 \mathrm{rpm}$. 


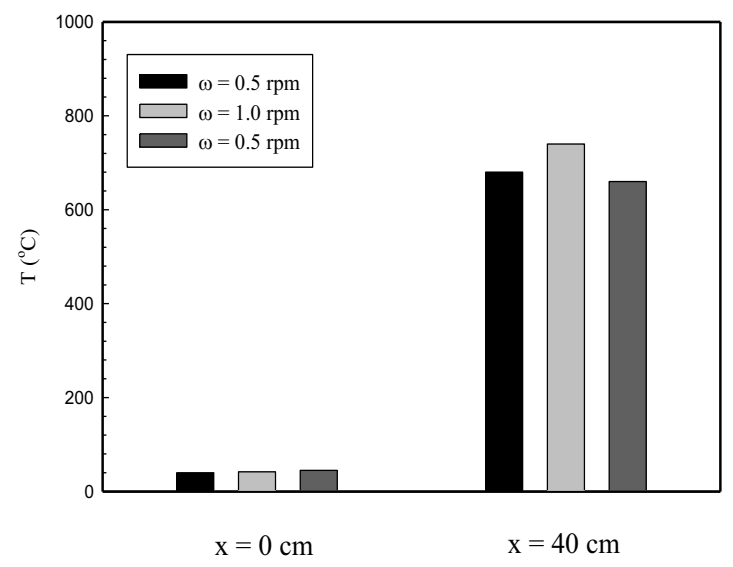

Fig. 3. Effect of the rotating velocity of combustion chamber $(\omega)$ on the temperature (T).

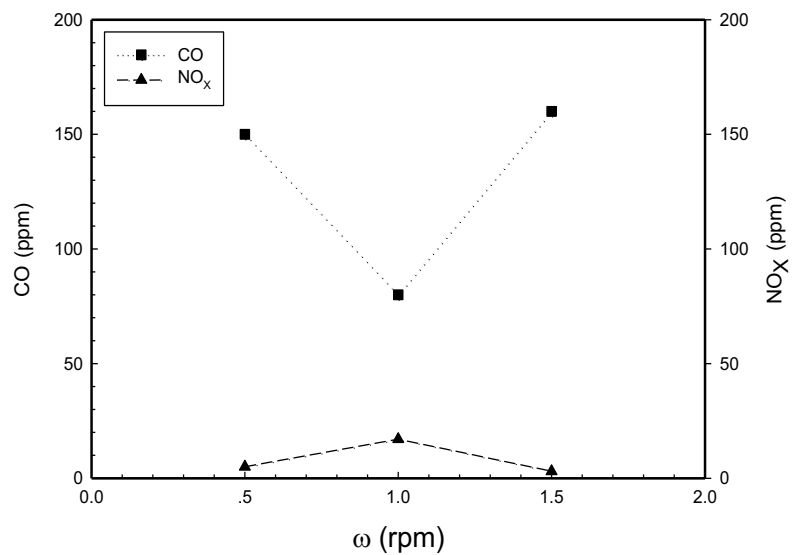

Fig. 4. Effect of the rotating velocity of combustion chamber $(\omega)$ on the content of exhaust gas $(\mathrm{CO}$ and $\mathrm{NO} \mathrm{x})$.

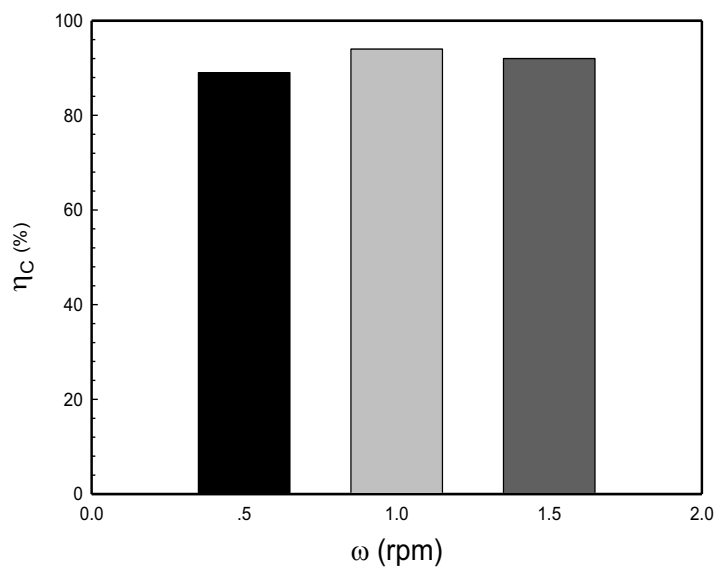

Fig. 5. Effect of the rotating velocity of combustion chamber $(\omega)$ on the combustion efficiency $\left(\eta_{c}\right)$. 


\subsection{Effect of the air flow rates $\left(Q_{A}\right)$}

Figure 6 showed the effect of air flow rates $\left(\mathrm{Q}_{\mathrm{A}}\right)$ on the $\mathrm{T}_{\text {in }}$ and $\mathrm{T}_{\text {exit. }}$. The condition studied in the experiment was the fuel load input rate $\left(\mathrm{Q}_{\mathrm{F}}\right)$ of $2.3 \mathrm{~kg} / \mathrm{h}, \mathrm{H}=4.2 \mathrm{~mm}$ and $(\phi)=0.82$. It was found that the trend of the $T_{\text {in }}(x=0 \mathrm{~cm})$ was in average of $40-45^{\circ} \mathrm{C} . \mathrm{T}_{\text {exit }}(\mathrm{x}=40 \mathrm{~cm})$ was increased as increasing $Q_{A}$ from 20 to $40 \mathrm{~m}^{3} / \mathrm{h}$ owing to because the fractional mixture between a fuel (rice husk) and the air was improved and sufficient for mechanisms of combustion leading to $\mathrm{CO}$ was decreased as shown in Figure 7. Similar results were also found in the literature [9]. The level of $\mathrm{NO}_{\mathrm{X}}$ was quite low as increasing $\mathrm{Q}_{\mathrm{A}}$ and was in the range not over $40 \mathrm{ppm}$. Similar phenomena of thermal $\mathrm{NO}_{\mathrm{X}}$ process had also been found in the literature [9]. Figure 8 showed that the $\eta_{C}$ was increased slightly with $\mathrm{Q}_{\mathrm{A}}$.

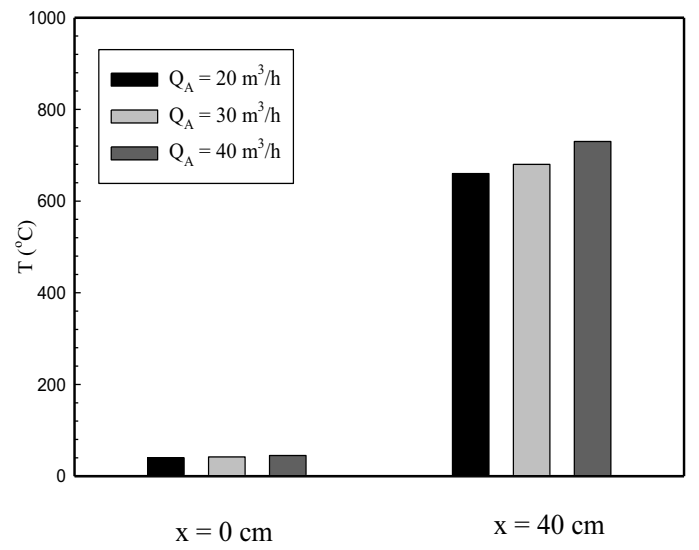

Fig. 6. Effect of the air flow rates $\left(\mathrm{Q}_{\mathrm{A}}\right)$ on the temperature $(\mathrm{T})$.

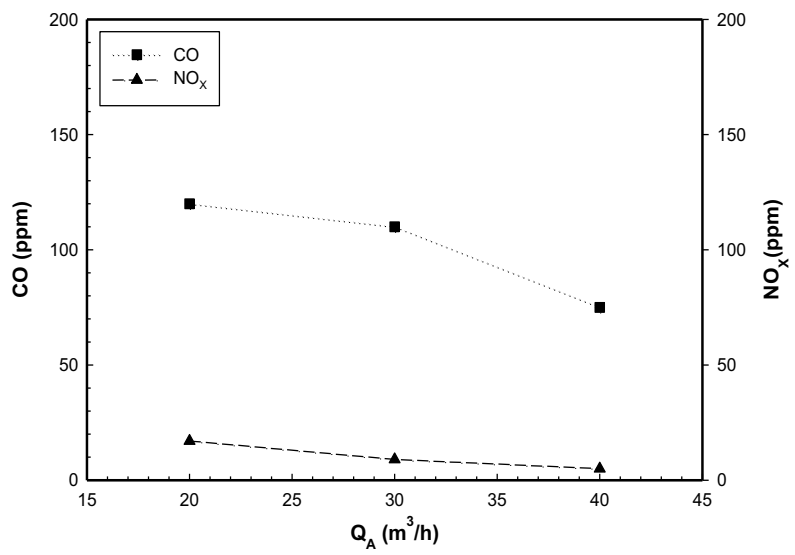

Fig. 7. Effect of the air flow rates $\left(\mathrm{Q}_{\mathrm{A}}\right)$ on the content of exhaust gas $\left(\mathrm{CO}\right.$ and $\left.\mathrm{NO}_{\mathrm{X}}\right)$. 


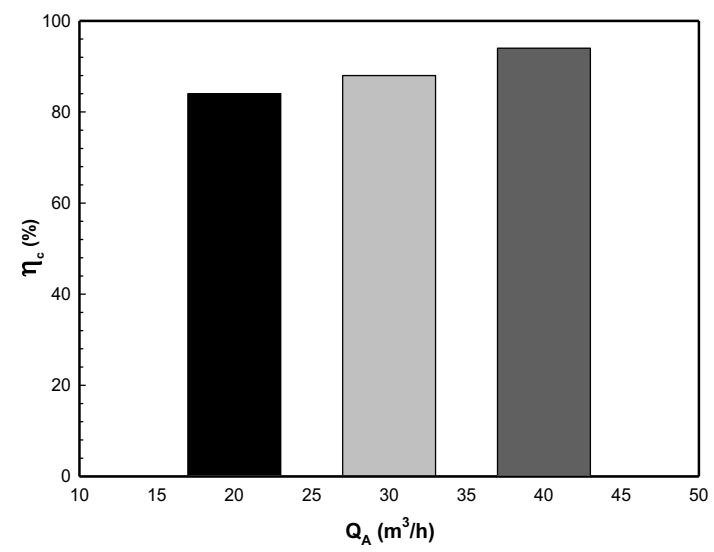

Fig. 8. Effect of the air flow rates $\left(Q_{A}\right)$ on the combustion efficiency $\left(\eta_{c}\right)$.

\subsection{Effect of the fuel load input rate $\left(Q_{F}\right)$}

Figure 9 showed the effect of the fuel load input rate $\left(\mathrm{Q}_{F}\right)$ on the $\mathrm{T}_{\text {in }}$ and $\mathrm{T}_{\text {exit }}$. The condition studied in the experiment was the fuel air flow rate $\left(\mathrm{Q}_{\mathrm{A}}\right)$ of $40 \mathrm{~m}^{3} / \mathrm{h}, \mathrm{H}=4.2 \mathrm{~mm}, \phi=0.82$. The trend of $T_{\text {in }}(x=0 \mathrm{~cm})$ was in average of $40-45^{\circ} \mathrm{C}$. The maximum $T_{\text {exit }}(\mathrm{x}=40 \mathrm{~cm})$ was appeared at $\mathrm{Q}_{\mathrm{F}}=2.3 \mathrm{~kg} / \mathrm{h}$. Similar results were also found in the literature [9]. However, the $\mathrm{T}$ was lower for $\mathrm{Q}_{\mathrm{F}}=2.9 \mathrm{~kg} / \mathrm{h}$ due to $\mathrm{Q}_{\mathrm{F}}$ was too high resulting to fuel can not burnt almost. Additionally, the amount of $\mathrm{CO}$ and $\mathrm{NO}_{\mathrm{X}}$ were shown in Figure 10. The minimum $\mathrm{CO}$ was yielded at $\mathrm{Q}_{\mathrm{F}}$ of $2.3 \mathrm{~kg} / \mathrm{h}$. The level of $\mathrm{NO}_{\mathrm{X}}$ was quite low as increasing $\mathrm{Q}_{\mathrm{F}}$ and was not over $40 \mathrm{ppm}$. Figure 11 showed the effect of $Q_{F}$ on the $\eta_{C}$. The $\eta_{C}$ was in the range of $93-95 \%$.

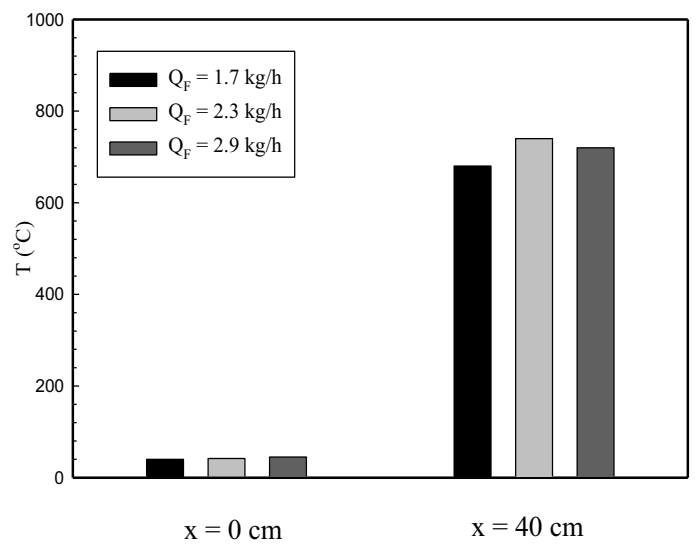

Fig. 9. Effect of the fuel load input rate $\left(\mathrm{Q}_{\mathrm{F}}\right)$ on the temperature $(\mathrm{T})$. 


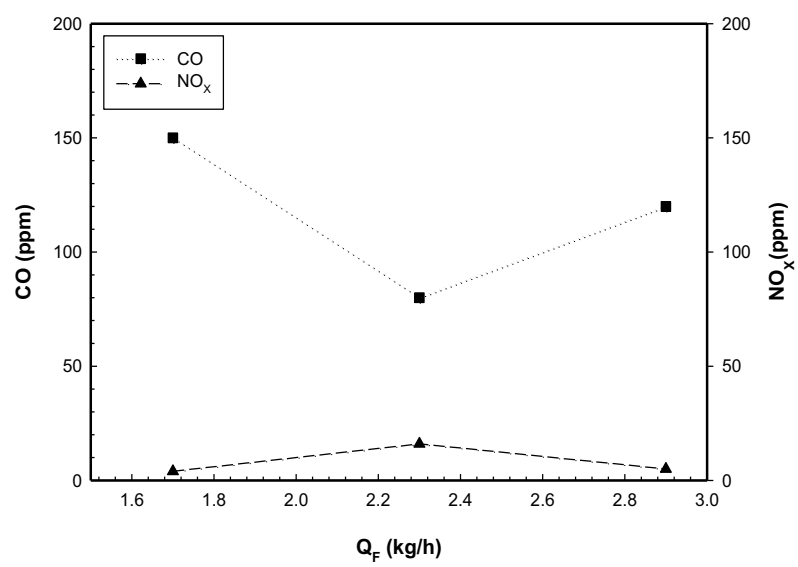

Fig. 10. Effect of the fuel load input rate $\left(\mathrm{Q}_{\mathrm{F}}\right)$ on the content of exhaust gas $\left(\mathrm{CO}\right.$ and $\left.\mathrm{NO} \mathrm{O}_{\mathrm{X}}\right)$.

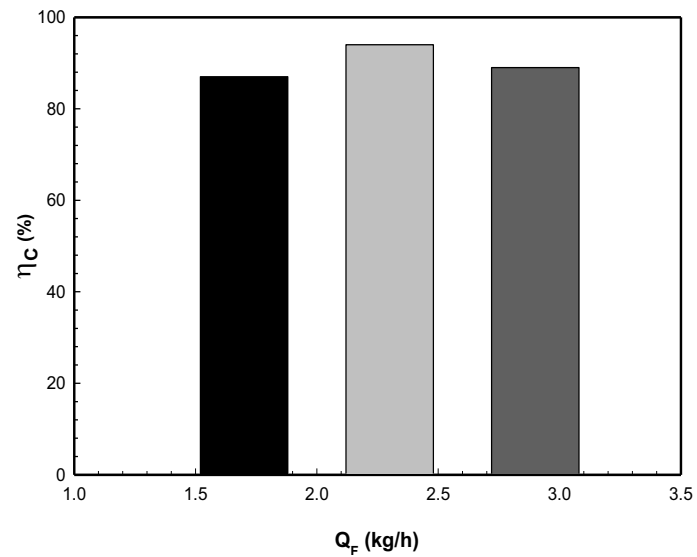

Fig. 11. Effect of the fuel load input rate $\left(Q_{F}\right)$ on the combustion efficiency $\left(\eta_{c}\right)$.

\section{Conclusions}

1. The trend of $T_{\text {in }}(x=0 \mathrm{~cm})$ was in average of $40-45^{\circ} \mathrm{C} . \mathrm{T}_{\text {exit }}(\mathrm{x}=40 \mathrm{~cm})$ was maximum at $\omega=1.0 \mathrm{rpm}$ in the examined range of $0.5-1.0 \mathrm{rpm}$. $\mathrm{T}_{\text {exit }}$ had a downward trend of $\mathrm{T}_{\mathrm{in}}$. The CO was minimum at $\omega=1.0 \mathrm{rpm}$ and the $\mathrm{NO}_{\mathrm{X}}$ was quite not changed (not over $40 \mathrm{ppm}$ ). The maximum $\eta_{\mathrm{C}}$ gave $93.7 \%$ at $\omega=1.0 \mathrm{rpm}$.

2. The trend of $T_{\text {exit }}(x=40 \mathrm{~cm})$ and $\eta_{C}$ were increased with $Q_{A}$ from 20 to $40 \mathrm{~m}^{3} / \mathrm{h}$. The $C O$ was decreased with $\mathrm{Q}_{\mathrm{A}}$ increasing and the $\mathrm{NO}_{\mathrm{X}}$ was quite not changed.

3. The maximum $T_{\text {exit }}(\mathrm{x}=40 \mathrm{~cm})$ was appeared at $\mathrm{Q}_{\mathrm{F}}=2.3 \mathrm{~kg} / \mathrm{h}$ in three examined cases $\mathrm{Q}_{\mathrm{F}} \geq: 1.7,2.3$ and $2.9 \mathrm{~kg} / \mathrm{h}$. The minimum $\mathrm{CO}$ contented for $\mathrm{Q}_{\mathrm{F}}=2.3 \mathrm{~kg} / \mathrm{h}$ but the $\mathrm{NO}_{\mathrm{X}}$ was very little changed. The $\eta_{C}$ was in the range of $93-95 \%$. 
The authors would like to express our thanks to the Energy Polocy and Planning Office (EPPO) for the research fund. Gratefully thanks to Dr. Panusak Moonsri for the revision of grammar in our first manuscript.

\section{References}

1. R. Echigo, Effective energy convection method between enthalpy and thermal radiation and application to industrial furnace, in Proceeding of the $7^{\text {th }}$ Heat Transfer conference, 6-10 September 1982, Munich, Germany, (1982)

2. M. Kaplan, M.J. Hall, Exp Therm Fluid Sci. 11, 13-20 (1995)

3. J.R. Howell, M.J. Hall, J.L. Ellzey, Prog Energ Combust. 22, 121-145 (1996)

4. H. Takami, T. Suzuki, Y. Itaya, M. Hasatani, Fuel. 165-171 (1998)

5. S. Jugjai, N. Wongpanit, T. Laoketkan, S. Nokkaew, Exp Therm Fluid Sci. 25, 15-23 (2002)

6. S. Jugjai, C. Pongsai, Combust Sci Technol. 179, 1823-1840 (2007)

7. T. Lakpradit, B. Krittacom, EITR\&D. 2, 36-44 (2013)

8. B. Krittacom, P. Amatachaya, The Effect of Porous Emitter on the Combustion of Diesel Oil Porous Burner, in Proceeding of the Second TSME International Conference on Mechanical Engineering, TSME-ICOME, 19-20 October 2011, Krabi, Thailand (2011)

9. K. Keawchart, B. Krittacom, Energy Procedia. 138, 2-7 (2017) 